\title{
Maternal Energy Intake at the Sixth Month as Dominant Factor of Exclusive Breastfeeding Success
}

\author{
Konsumsi Energi Ibu Bulan Keenam sebagai Faktor Dominan Keberhasilan \\ ASI Eksklusif
}

Devi Suryanti Sihite*, Sandra Fikawati**, Ahmad Syafiq**

*Health Office of Central Tapanuli, Tapanuli, Indonesia, **Center for Nutrition and Health Studies, Faculty of Public Health, Universitas Indonesia, Depok, Indonesia

\begin{abstract}
Breastfeeding mothers needed adequate energy intake to provide 6-month exclusive breastfeeding that is necessary for infant growth and development. This study aimed to investigate real intake at the first and sixth month of breastfeeding and determine the dominant factor affecting 6-month exclusive breastfeeding provision. The design of this study was cross-sectional conducted in March-April 2015 among 109 mothers with 6-12-month-old infant living and registered at integrated health care in Kalangan Primary Health Care area. Data were collected through interview using questionnaires. Breastfeeding mothers' intake was asked using Semi-Quantitative Food Frequency Questionnaire. The study found that 6-month exclusive breastfeeding proportion was $22.9 \%$. Mean energy intake of breastfeeding mothers declined from $2551 \mathrm{kcal} /$ day in the first month of breastfeeding to $1718 \mathrm{kcal} /$ day in the sixth month of breastfeeding. After controlled by other variables, energy intake in the sixth month of breastfeeding was found to be the most dominant factor affecting 6-month exclusive breastfeeding provision. Mothers with low energy intake at the sixth month of breastfeeding period were likely 9 times more to fail in providing 6-month exclusive breastfeeding compared to those with adequate energy intake.
\end{abstract}

Keywords: Exclusive breastfeeding, energy intake

\begin{abstract}
Abstrak
Ibu menyusui memerlukan konsumsi energi yang cukup selama menyusui untuk bisa memberikan ASI eksklusif 6 bulan yang dibutuhkan untuk pertumbuhan dan perkembangan bayi. Penelitian ini bertujuan mengetahui besar konsumsi energi ibu menyusui pada bulan pertama dan bulan keenam menyusui serta faktor dominan yang berhubungan dengan pemberian ASI eksklusif 6 bulan. Penelitian dengan desain potong lintang ini dilaksanakan Maret-April 2015 pada 109 ibu yang memiliki bayi berusia 6-12 bulan yang terdaftar di posyandu dan bermukim di wilayah kerja Puskesmas Kalangan. Data dikumpulkan melalui wawancara langsung dengan menggunakan kuesioner. Data konsumsi energi ibu menyusui diperoleh menggunakan Food Frequency Questionnaire semi kuantitatif. Persentase pemberian ASI eksklusif di wilayah kerja Puskesmas Kalangan sebesar 22,9\%. Rata-rata konsumsi energi ibu menyusui menurun dari $2551 \mathrm{kkal} / \mathrm{hari}$ pada bulan pertama menjadi $1718 \mathrm{kkal} / \mathrm{hari}$ pada bulan keenam. Konsumsi energi bulan keenam merupakan faktor dominan pemberian ASI eksklusif 6 bulan $(\mathrm{OR}=8,9)$ setelah dikontrol variabel lainnya. Artinya, ibu dengan konsumsi energi rendah pada bulan keenam memiliki risiko 9 kali lebih besar tidak dapat memberikan ASI eksklusif 6 bulan dibandingkan dengan ibu yang konsumsi energinya cukup pada bulan keenam.
\end{abstract}

Kata kunci: ASI eksklusif, konsumsi energi

How to Cite: Sihite DS, Fikawati S, Syafiq A. Maternal energy intake at the sixth month as dominant factor of exclusive breastfeeding success. Kesmas: National Public Health Journal. 2017; 12(2): 87-92. (doi:10.21109/kesmas.v12i2.1470)
Correspondence: Sandra Fikawati, Center for Nutrition and Health Studies, Faculty of Public Health Universitas Indonesia Building F 2nd Floor Kampus Baru UI Depok 16424, Phone: +6221-7863501,E-mail: fikawati@ui.ac.id Received: Juny $20^{\text {th }} 2017$

Revised: September 6 2017

Accepted: October 6 2017 


\section{Introduction}

In the world, out of 136 million infants born every year, 92 million infants do not receive breast milk optimally. World Health Organization and United Nation Children's Fund recommend the optimum breastfeeding i.e. first, early initiation of breastfeeding within one hour of birth; second, exclusive breastfeeding within the first six months of life (6-month exclusive breastfeeding); third, appropriate timing for complementary feeding after 6 months of age; fourth, continued breastfeeding up to two years of age. 1,2

Survey shows that in Indonesia, coverage of 6-month exclusive breastfeeding is still under the determined target $(50 \%){ }^{3}$ Reports of Provincial Health Office all over Indonesia show that North Sumatera is at bottom five group in achievement of exclusive breastfeeding 0-6 months, only at $41.3 \% .^{5}$ According to Health Profile of North Sumatera Province in 2012, the achievement of exclusive breastfeeding since 2004-2012 tend to significantly decrease. The achievement of exclusive breastfeeding coverage in 2012 was the lowest achievement by $20.3 \%$. Furthermore, 8 of 33 districts/cities in North Sumatera achieve exclusive breastfeeding by $0 \%$ and one of them is Central Tapanuli District. ${ }^{5}$

Nutrition of breastfeeding mothers closely related to breast milk production. Breastfeeding mothers need balanced and adequate nutritional intake to meet the needs of energy, protein, fat, and other nutrients as well as water. Nutrition recommendation for breastfeeding mothers is larger than for pregnant mothers. ${ }^{6}$ Recently, most pregnant mothers already have the awareness of the importance of maintaining healthy pregnancy by completing nutritional needs. However, after giving birth, there are many mothers who immediately reduce and even limit food, so the nutritional intake is decreasing if compared to the time of pregnancy. ${ }^{7}$

Most mothers still often ignore the energy intake during breastfeeding, so energy consumption of breastfeeding mothers becomes lower than energy consumption of pregnant mothers. A study among groups of vegetarian and non-vegetarian mothers in five big cities in Indonesia showed that the energy intake of mothers during breastfeeding is lower significantly than during pregnancy. ${ }^{8}$ The low energy intake of vegetarian mothers affects the lower weight of mothers significantly in six months after exclusive breastfeeding compared to the non-vegetarian mothers, yet it does not affect their infants. ${ }^{9}$ Study reported that breastfeeding mothers require higher energy consumption, since the amount of energy consumption affects quality and quantity of breastmilk production. ${ }^{10}$

A qualitative study in Jakarta and Depok reported that causes of the low energy intake of breastfeeding mothers including the lack of knowledge and attitude regarding the high nutritional needs during breastfeeding, bustle of mothers about taking care of their infants so mothers feel tired to cook and eat, a reduction in milk and supplement consumptions, avoided food, and minimum information from health officers regarding nutritional needs for breastfeeding mothers. ${ }^{11}$ In Africa, the success of exclusive breastfeeding related to the number of family members. Extended families were found to be more successful in exclusive breastfeeding. ${ }^{12}$ Moreover, any difficulties occur in early period of breastfeeding. A study also shows that energy intake of mothers decreases during breastfeeding period as shown by significant differences between maternal energy intake in the first month and in the sixth month. 8,13

This study aimed to determine proportion of 6-month exclusive breastfeeding, the amount of energy intake of breastfeeding mothers in the early exclusive breastfeeding (the first month) and the late exclusive breastfeeding (the sixth month), and the dominant factor related to 6-month exclusive breastfeeding in the working area of Kalangan Primary Health Care, Central Tapanuli District, North Sumatera Province. Exclusive breastfeeding achievement of North Sumatra Province since 2004-2012 tends to decline significantly and the lowest achievement of exclusive breastfeeding is in 2012 at $20.33 \%$. Kalangan Primary Health Care in Central Tapanuli District is one of the district's area with $0 \%$ exclusive breastfeeding achievements in 2012.

\section{Method}

Study with cross-sectional design was conducted in March-April 2015 in the working area of Kalangan Primary Health Care, Central Tapanuli District, North Sumatera Province. The population was all mothers who had infants aged older than 6-12 months were registered in integrated health care and living in working area of Kalangan Primary Health Care. The sample were 109 mothers-infants. Data were collected through direct interview to respondents by questionnaire. There were two data collectors from Kalangan Primary Health Care.

The dependent variable in this study was provision of exclusive breastfeeding to six months, while the main independent variable was the energy intake of breastfeeding mothers. The operational definition of exclusive breastfeeding to six months is that infants receive only breast milk for six months, no other foods or drinks were given, except medicines. ${ }^{1,14}$ Meanwhile, predominant breastfeeding means breast milk as the major source of infant's food, but in addition to breast milk, the infant also receives water and water-based drinks (sweet and natural taste, tea, infusion, etc), fruit juice; oral rehydration solutions (ORS), drops and syrups (vitamin, mineral and medicines), and ritual fluids in limited amount. ${ }^{1}$ In this area, 6-month exclusive breastfeeding, as defined by WHO, is very difficult to find because of unsupportive lo- 
Table 1. Variable Distribution of Exclusive Breastfeeding, Energy Intake, and Confounding Variables

\begin{tabular}{|c|c|c|c|}
\hline Variable & Category & $\mathbf{n}$ & $\%$ \\
\hline \multirow[t]{2}{*}{ Exclusive breastfeeding } & No & 84 & 77.1 \\
\hline & Yes & 25 & 22.9 \\
\hline \multirow[t]{2}{*}{ Energy intake of the first month of breastfeeding } & Less $(<2100 \mathrm{kcal})$ & 50 & 45.9 \\
\hline & Enough ( $\geq 2100 \mathrm{kcal})$ & 59 & 54.1 \\
\hline \multirow[t]{2}{*}{ Energy intake of the sixth month of breasfeeding } & Less $(<2100 \mathrm{kcal})$ & 83 & 76.1 \\
\hline & Enough ( $\geq 2100 \mathrm{kcal})$ & 26 & 23.9 \\
\hline \multirow[t]{2}{*}{ Mothers'education level } & Low (primary and junior high) & 66 & 60.6 \\
\hline & High (senior high and university) & 43 & 39.4 \\
\hline \multirow[t]{2}{*}{ Parity } & Primiparous & 20 & 18.3 \\
\hline & Multiparous & 89 & 81.7 \\
\hline \multirow[t]{2}{*}{ Mothers' occupation } & Working & 24 & 22.0 \\
\hline & Not working & 85 & 78.0 \\
\hline \multirow{2}{*}{ Knowledge of breastfeeding } & Low $(<75 \%$ correct answer $)$ & 87 & 79.8 \\
\hline & High ( $>75 \%$ correct answer) & 22 & 20.2 \\
\hline \multirow{2}{*}{ Attitude } & Negative ( $\leq$ mean) & 10 & 9.2 \\
\hline & Positive (> mean) & 99 & 90.8 \\
\hline \multirow{2}{*}{ ANC status } & Not according to ANC standard ANC & 51 & 46.8 \\
\hline & ANC standard & 58 & 53.2 \\
\hline \multirow{2}{*}{ IMD status } & No IMD & 109 & 100.0 \\
\hline & IMD & 0 & 0.0 \\
\hline \multirow[t]{2}{*}{ Exposed samples of formula } & Yes & 3 & 2.8 \\
\hline & No & 106 & 97.2 \\
\hline \multirow[t]{2}{*}{ Skill of breasfeeding technique } & Difficult breastfeeding & 71 & 65.1 \\
\hline & Good breastfeeding & 38 & 34.9 \\
\hline \multirow[t]{2}{*}{ Husband's support } & Not support & 71 & 65.1 \\
\hline & Support & 38 & 34.9 \\
\hline \multirow[t]{2}{*}{ Health workers' support } & Not support & 61 & 56.0 \\
\hline & Support & 48 & 44.0 \\
\hline
\end{tabular}

Notes:

$\mathrm{n}=$ Number of sample

cal culture, such as the culture of providing prelacteal feeds. Study shows that predominant breastfeeding is not different with exclusive breastfeeding in relation to risk of infant death. 15

Data of breastfeeding mothers' energy intake were obtained from direct interview by using FFQ semi-quantitative to breastfeeding mothers. Data were obtained by measuring breastfeeding mother once in the first month and once in the sixth month post-partum. The energy intake of breastfeeding mothers was classified into two categories, namely less energy intake $(<2100 \mathrm{kcal})$ and sufficient energy intake $(\geq 2100 \mathrm{kcal}) .{ }^{8}$ The obtained data used univariate, bivariate, and multivariate analysis. Bivariate analysis used chi-square analyisis and multivariate analysis used multiple logistic regression test.

\section{Results}

Proportion of exclusive breastfeeding in working area of Kalangan Primary Health Care, Central Tapanuli District in 2015 was only $22.9 \%$. Proportion of sufficient energy intake in the first month was $54.1 \%$ and the sufficient energy intake in the sixth month decreased to $23.9 \%$ (Table 1). Breastfeeding mother respondents generally had low level of education (elementary and junior high school) $(60.6 \%)$, poor knowledge $(79.8 \%)$, unemployed $(78.0 \%)$ and had more than one child $(81.7 \%)$.
Table 2. The Average of Energy Intake

\begin{tabular}{|c|c|c|c|c|c|}
\hline Periode of Intake & $\mathbf{n}$ & Mean & SD & Min-max & p Value \\
\hline First month & 109 & 2551 & 1247.5 & $633-6779$ & 0.000 \\
\hline Sixth month & & 1718 & 936.8 & $375-5207$ & \\
\hline
\end{tabular}

Notes:

$\mathrm{SD}=$ Standard Deviation

None of the mothers took early initiation of breastfeeding, also supports from husbands and health officers were relatively low (less than $50 \%$ ). However, most mothers had a positive attitude $(90.8 \%)$ and mothers almost never got exposed to formula milk advertising $(97.2 \%)$ (Table 1).

The average energy intake of breastfeeding mothers in the first month was $2551 \mathrm{kcal}$ and $1718 \mathrm{kcal}$ in the sixth month. The difference of mean value between the first and the sixth month was quite large at $833 \mathrm{kcal}$. The result of statistical test showed that there was significant difference of breastfeeding mothers' energy intake in the first and in the sixth month (Table 2).

The results of multivariate analysis showed that the dominant variable significantly related to 6-month exclusive breastfeeding was energy intake in the sixth month after controlled with other variables. Odds ratio value of energy intake of breastfeeding mothers in the sixth month 
Table 3. Multivariate Analysis Result

\begin{tabular}{lrcrcr}
\hline \multicolumn{1}{c}{ Variable } & $\boldsymbol{\beta}$ & SE & p Value & OR & \multicolumn{1}{c}{$\mathbf{9 5 \%}$ CI } \\
\hline Energy intake of the first month & -1.219 & 0.717 & 0.089 & 0.30 & $0.07-1.21$ \\
Energy Intake of the sixth month & 2.197 & 0.726 & 0.002 & 9.00 & $2.17-37.35$ \\
Education level & -1.734 & 0.752 & 0.021 & 0.18 & $0.04-0.77$ \\
Knowledge & 2.017 & 0.783 & 0.010 & 7.51 & $1.62-34.85$ \\
Husband support & 0.672 & 0.651 & 0.302 & 1.96 & $0.55-7.02$ \\
Occupotional & -0.737 & 0.644 & 0.252 & 0.48 & $0.14-1.69$ \\
Health workers support & 1.106 & 0.569 & 0.052 & 3.02 & $0.99-9.21$ \\
\hline
\end{tabular}

Notes:

$\mathrm{SE}=\mathrm{Standard}$ Error; $\mathrm{OR}=$ Odds Ratio

was $9.0(95 \%$ CI: $2.2-37.4)$ which means that breastfeeding mothers who received less energy intake in the sixth month were 9 times higher at risk not to breastfeed exclusively to six months compared to breastfeeding mothers who received sufficient energy intake in the sixth month (Table 3).

\section{Discussion}

In accordance with data on the extent of exclusive breastfeeding from the Health Profile of North Sumatera Province, this study showed that exclusive breastfeeding prevalence in the working area of Kalangan Primary Health Care, Central Tapanuli District was low, only at $22.9 \%$. Most mothers did not breastfeed exclusively. Low exclusive breastfeeding in this area may be caused by low education, knowledge, socio-economic status and less support from family and community. Inappropriate marketing of formula milk is considered detrimental to mothers' perception of exclusive breastfeeding and so it would be expected to decrease rates of exclusive breastfeeding to six months.

This study found that the average energy intake of breastfeeding mothers decreased from $2551 \mathrm{kcal} /$ day in the first month to $1718 \mathrm{kcal} /$ day in the sixth month. This result was in line with a previous study which showed that energy intake of breastfeeding mothers decreased continuously throughout the breastfeeding period. 8,13 These levels did not fully meet the recommendation from the Nutrient Adequacy Ratio in Indonesia that energy intake of breastfeeding mothers should increase from +330 $\mathrm{kcal} /$ day for the first six months of life to $+400 \mathrm{kcal} /$ day for the next six months though in the first month is adequate. The intake in the first month is adequate but not for the sixth months' intake.

It is important that mothers provide sufficient breastmilk to support the rapid growth of infants. Reduced energy intake may decrease the ability of mothers to breast-feed exclusively. ${ }^{13}$ In less developed areas, many mothers suffer from chronic energy deficiency of exclusive breastfeeding with inadequate quantity and quality of breast milk, which affects the infant's nutritional sta- tus. ${ }^{16}$ Mohammad, Sunehag \& Haymond, 17 reported that studies in breastfeeding women from the United States and Sweden concluded that women can successfully breastfeed their infants if they have been provided calorie intakes of $1800-2200 \mathrm{kcal} /$ day. ${ }^{17}$ Fikawati, ${ }^{8}$ found that mothers that consumed $\geq 2100 \mathrm{kcal} /$ day were more able to breastfeed exclusively for six months compared to mothers who consumed less energy.

This study used multivariate analysis to determine dominant factors in continuation of exclusive breastfeedingto six months. Energy intake in the sixth month was the dominant factor for exclusive breastfeeding to six months. Mothers with decreased energy intake had a 9times higher chance of not exclusively breastfeeding for 6 months than those with a higher energy intake. This is concordant with a study conducted in Bekasi by Syafiq, Fikawati and Widiastuti, ${ }^{13}$ which found that average energy intake decreased through the breastfeeding period and that mothers with low energy intake had a 4-times higher chance of early cessation of breastfeeding. Fikawati, Syafiq and Mardatillah, ${ }^{18}$ also found that exclusive breastfeeding to six months correlated significantly with a higher energy intake.

This study showed that the main cause for failure of exclusive breastfeeding before six months was low energy intake of the mother during breastfeeding period. Reasons that mothers consume less calories than recommended may include mothers not consuming sufficient calories since the beginning of pregnancy, striving to return to pre-pregnancy body weight, not having access to sufficient food especially early in breastfeeding period, limited knowledge and motivation about high nutritional needs while breastfeeding, mother foregoing meals due to fatigue from caring for infant, decrease of supplement intake and infant's milk consumption, dietary restrictions, insufficient information about intake requirements from health workers, and mothers' failure to account for daily increases in energy requirements. ${ }^{11,18}$

Gonzales, Habicht, Rasmussen, and Delgado, ${ }^{19}$ found that mothers with higher energy intake had higher rates of exclusive breastfeeding to 20 weeks after giving birth 
compared to those with a low energy intake. Syafiq, Fikawati \& Widiastuti, ${ }^{13}$ reported that mothers with low energy consumption during breastfeeding had 4 times higher risk of short duration of breastfeeding. Expectant mothers may gain 1-2 kg of fat during pregnancy which can subsequently be utilized during breastfeeding.

However, other studies have suggested that energy intake of mothers is important from the start of breastfeeding. One such study found that insufficient energy intake from the beginning of breastfeeding leads to insufficient fat stores to support breastfeeding after the fourth month. ${ }^{17}$ Insufficient milk production may lead to anxiety of the mother about whether to continue exclusive breastfeeding orprovide formula milk to supplement or replace breast-milk (weanling's dilemma). ${ }^{20}$

Olson, ${ }^{21}$ showed that mothers who are successful in breastfeeding usually have a balanced diet. To support milk production and prevent malnutrition in mothers, breastfeeding women must increase their energy intake above the general recommended level for adult women. ${ }^{22}$ In addition to supporting successful milk production, added calories are utilized for post-birthing recovery. Balanced food intake while breastfeeding is a very important component in attaining optimal health for mothers and infants. ${ }^{23}$

Mothers with insufficient fat reserves, commonly with low socio-economic status, may be forced to breastfeed exclusively leading to catabolization of the tissues of the mother to support milk-production leading to malnourishment of the mother. ${ }^{9}$ It may be considered that physiology prioritizes support of the infant as significant tissue catabolism will occur before milk-production is affected. ${ }^{24}$

In Indonesia, the availability of information regarding the high nutrition and energy requirements while breastfeeding is poor. ${ }^{8}$ A study in Bogor of 220 breastfeeding mothers found that average energy and protein intake was $70 \%$ lower than recommend levels and intake of $\mathrm{Fe}$, $\mathrm{Ca}, \mathrm{Zn}$, vitamin $\mathrm{A}$ and vitamin $\mathrm{C}$ were $77 \%$ lower than recommended levels. ${ }^{25}$ However, that study also found that vegetable intake doubled compared to before pregnancy intake as mothers considered that it would improve their breastfeeding performance. ${ }^{25}$ This is consistent with information provided for breastfeeding mothers, such as suggestions to eat diverse foods; increase fruit, vegetable and water consumption; and good breastfeeding tips. However, advice is not given regarding the high-energy requirements for breastfeeding mothers.

\section{Conclusion}

The prevalence of six-month exclusive breastfeeding is low at $22.9 \%$. The average energy intake of breastfeeding mothers in the first month is sufficient at 2551 $\mathrm{kcal} /$ day, however, this figure continuously decreases to only $1718 \mathrm{kcal} /$ day in the sixth month. Energy intake in the sixth month is the most significant contributing factor to six-month exclusive breastfeeding, after controlling for the variables energy intake in first month, education, knowledge, support from husband, occupation, and support from health workers, with OR $=9.0$ (95\% CI: 2.17 37.35). This means that mothers with low energy intake at the sixth month of breastfeeding period would have 9 times higher chance to fail providing 6-month exclusive breastfeeding compared to those with adequate energy intake.

\section{Recommendation}

To achieve the target of 6-month exclusive breastfeeding, attention must be paid to achieving sufficient nutrition for breastfeeding mothers from the first to the sixth month of breastfeeding. It is suggested for government to plan supplementation program for breastfeeding mothers especially in the second three months. Another study should be conducted to explore the reason of declining energy intake during breastfeeding.

\section{References}

1. World Health Organization. Global strategy for infant and young child feeding. Geneva: World Health Organization; 2003.

2. United Nation Children's Fund. infant and young child feeding. Programming guide. New York: United Nation Children's Fund; 2011 [cited 23 September 2015]. Available from: www.unicef.org

3. Republik Indonesia. Pedoman perencanaan progam gerakan nasionalsadar gizi dalam rangka 1000 hari pertama kehidupan. Jakarta: Bappenas Republik Indonesia; 2012.

4. Kementrian Kesehatan Republik Indonesia. Barometer gizi. Jakarta: Kementerian Kesehatan Republik Indonesia; 2014.

5. Dinas Kesehatan Provinsi Sumatera Utara. Profil kesehatan sumatera utara tahun 2012. Medan: Dinas Kesehatan Provinsi Sumatera Utara; 2013.

6. Kementerian Kesehatan Republik Indonesia. Angka kecukupan gizi yang dianjurkan bagi bangsa Indonesia. Jakarta: Direktorat Bina Gizi dan KIA Kementrian Kesehatan Republik Indonesia; 2014.

7. Irianto K. Gizi seimbang dalam kesehatan reproduksi. Bandung: Alfabeta; 2014.

8. Fikawati S. Pengaruh diet vegetarian dan nonvegetarian terhadap status gizi ibu, durasi ASI predominan, dan pertumbuhan bayi: Studi Kohort di 5 Kota. [Disertasi]. Depok: FKM, Universitas Indonesia; 2013.

9. Fikawati S, Syafiq A, Kusharisupeni, Irawati A, Karima K. Comparison of breastfeedingal performance of vegetarian and non-vegetarian mothers in Indonesia. Malaysian Journal of Nutrition. 2014; 20(1): 15 - 25.

10. Gilchrist M. Relations between diets of breastfeeding women, socioeconomic status and stress. [Doctoral dissertation]. Oklahoma: Oklahoma State University; 2011.

11. Fikawati S, Syafiq A, Purbaningrum RP, Karima K. Energy consumption of breastfeeding mothers: Current situation and problems. Makara Journal Health Research. 2014; 18(2): 58-64.

12. Ukegbu PO. Anyika-Elekeh JU. Influence of maternal characteristics on 
exclusive breastfeeding practice among urban others in Umuahia. Nigeria. Malaysian Journal of Nutrition. 2013; 19(3): 311-23.

13. Syafiq A, Fikawati S, Widiastuti R. Energy consumption during breastfeeding and durationof breastfeeding at Puskesmas Margajaya Bekasi City in 2014. Makara Journal Health Research. 2015; 19(2): 81-6.

14. Kementrian Kesehatan Republik Indonesia. Pedoman pembentukan dan pembinaan kelompok pendukung ibu menyusui. Jakarta: Kementerian Kesehatan Republik Indonesia; 2012.

15. Bahl R, Frost C, Kirkwood BR, Edmond K, Martines J, Bhandari N, Arthur P. Infant feeding patterns and risks of death and hospitalization in the first half of infancy: Multicentre cohort study. Bulletin of the World Health Organization. 2005; 83: 418-26.

16. Fikawati S, Syafiq A, Karima K. Gizi ibu dan bayi. Jakarta: PT. Rajagrafindo Persada; 2015.

17. Mohammad M, Sunehag A, Haymond M. Effect of dietary macronutrient composition under moderate hypocaloric intake on maternal adaptation during breastfeeding. American Journal of Clinical Nutrition. 2009; 89: 1821

18. Fikawati S, Syafiq A, Mardatillah. Maternal calorie intake is a significant factor associated with 6 months exclusive breastfeeding among breastfeeding mothers in Depok City. Indonesia. Malaysian Journal of Nutrition. 2017; 23 (1): 1-11.
19. Gonzales T, Habicht JP, Rasmussen KM, Delgado HL. Impact of food. supplementation during breastfeeding on infant breast-milk intake and on the proportion of infants exclusively breast-fed. American Society for Nutritional Sciences. 1998; 128: 1692-00702.

20. Kramer MS, Kakuma R. Optimal duration of exclusive breastfeeding. The Cochrane Collaboration. Canada: John Willey \& Sons. Ltd.; 2009.

21. Olson CM. Tracking of food choices across the transition to motherhood. Journal Nutrition Education Behavior. 2005; 37(3): 129-36.

22. Chen H, Wang P, Han Y, Ma J, Toy II FA, Wang B. Evaluation of diatery intake of breastfeeding women in China and its potential impact on the health of mothers and infants. BMC Women's Health. 2012; 12: 18.

23. Doran L, Evers S. Energy and nutrient inadequacies in the diets of lowincome women who breast-feed. Journal of The American Dietetic Association. 1997; 11: 1283-1287.

24. Dewey KG. Energy and protein requirements during breastfeeding. Annual Review of Nutrition.1997; 17: 19-36.

25. Madanijah S, Rimbawan R, Briawan D, Zulaikhah Z, Andarwulan N, Nuraida L. Nutritional status of breastfeeding women in Bogor District, Indonesia: cross-sectional dietary intake in three economic quintiles and comparison with pre-pregnant women. British Journal of Nutrition. 2016; 116 (S1): S67- S74. 